\title{
Teachers' Awareness Regarding Emergency Management of Epistaxis inside the School; Alahssa, Saudi Arabia
}

\author{
Fatimah Alshehri, Fatimah Alluwaim, Khalid Alyahya \\ Faculty of Medicine, King Faisal University, Al-Hassa, KSA \\ Email: fatmaalshehri26@gmail.com
}

How to cite this paper: Alshehri, F., Alluwaim, F. and Alyahya, K. (2018) Teachers' Awareness Regarding Emergency Management of Epistaxis inside the School; Alahssa, Saudi Arabia. Open Journal of Preventive Medicine, 8, 44-55.

https://doi.org/10.4236/ojpm.2018.82005

Received: January 15, 2018

Accepted: February 25, 2018

Published: February 28, 2018

Copyright $\odot 2018$ by authors and Scientific Research Publishing Inc. This work is licensed under the Creative Commons Attribution International License (CC BY 4.0).

http://creativecommons.org/licenses/by/4.0/

\begin{abstract}
Background: Epistaxis is one of the commonest emergencies encountered by ENT physicians as well as to family and emergency physicians. It is common among school children as they are easily injured during different school activities. Objective: The aim of this study was to assess the level of knowledge and attitude regarding first aid management of epistaxis among school teachers in Al-Ahsa, Saudi Arabia. Method: A cross sectional study was conducted in November 2017 among Saudi school teachers in AlAhssa region, Kingdom of Saudi Arabia. The data were collected by a well-structured online questionnaire which was designed including questions about the biographical data of the teacher, questions about the past knowledge of the emergency management of epistaxis and questions assessing the awareness of the method applied as a management of epistaxis. Result: We received 485 valid responses. $76 \%$ of teachers were female, $93 \%$ worked in public and $40 \%$ were in primary schools. $54 \%$ of participants had received information about first aid to stop nose bleeding or hemorrhage. $67 \%$ said that their students experienced epistaxis before. Interestingly, $15 \%$ said they would not try to stop the bleeding, and only $25 \%$ said they would press on the cartilaginous part of nose. However, a higher percentage (57\%) knew that they should tilt the head forward.
\end{abstract}

\section{Keywords}

Epistaxis, Epistaxis in School, Awareness, Management, Al-Ahssa

\section{Introduction}

Epistaxis is defined as bleeding from the nose or nasopharynx. It is one of the 
most common ENT emergencies faced in the emergency departments worldwide [1]. $66.67 \%$ of population experience epistaxis during their lifetime. More than $50 \%$ of children between 6 and 10 years have suffered from at least one episode of epistaxis [2]. Approximately, 30\% of school-aged children's lifetime is spent in schools, which is a significant part of their lifetime and directly influences their physical and mental health [3] [4]. Most of this time on schools is spent under supervision of teachers; accordingly the teachers are the main personnel to deal with urgent health requirements during school hours [5]. Since schools do not typically have expert health care providers on the spot, it is fundamental for teachers to be trained to deal with emergencies and to be qualified to act correctly with health emergencies that affect school children [6] [7]. Unfortunately, in several countries, school health care services are disregarded. This factor participates in lacking of awareness and knowledge regarding first aid measures [8].

Although many studies have been published on the acute management of epistaxis, school teachers' knowledge and attitude about this subject have not been documented.

Thus, the aim of this study is to assess the level of knowledge and attitude regarding first aid management of epistaxis among school teachers in Alahssa, Saudi Arabia.

\section{Subjects and Methods}

\subsection{Study Design}

A cross sectional study was prepared to assess the awareness of the emergency management of epistaxis among teachers inside their schools.

\subsection{Sample Size}

Calculation of sample size was done to ensure the minimum number of respondents needed to be a representative sample for the whole teachers in AlAhsa. The sample size was determined using Raosoft sample size calculator [9]. Keeping an indicator percentage of 0.50 , margin of error of $5 \%$ and confidence interval (CI) of $95 \%$, the calculated sample size was 377.

\subsection{Study Area and Population}

This study was conducted in November 2017 among Saudi school teachers in AlAhssa region, Kingdom of Saudi Arabia.

\subsection{Ethical Clearance}

Ethical approval was obtained from the College of Medicine at King Faisal University before carrying out the study. An informed consent was obtained from each participant before entering the study. The confidentiality of information was maintained by assigning identification numbers (available to investigators only) for each participant. 


\subsection{Questionnaire Sheet}

A well-structured online questionnaire (Appendix) was designed in Arabic including 5 questions about the biographical data of the teacher: age, gender, nationality, specialty and type of school. Also, it includes 2 questions about the past knowledge of the emergency management of epistaxis and 9 questions assessing the awareness of the method applied as a management of epistaxis. This questionnaire was distributed among participants preceded by oral briefing for the aim of the study.

\subsection{Statistical Analysis}

All questionnaires coded and entered into a spreadsheet, then transferred into SPSS (version 23) for data analysis. Data were presented as frequencies and percentages. Also, the chi-square test was used for the comparison and to assess the possible associations of the teacher specialty and the awareness of management of epistaxis inside the school to the significant point (significant level $\mathrm{P}<0.05$ ).

\section{Results}

\subsection{General Biographical Data}

In the present cross-sectional study, we retrieved 485 surveys. Forty-five percent of our sample aged 36 - 45, 76\% were women, and all our participants were Saudi citizens. Table 1 shows distribution and baseline characteristics of our sample.

Table 1. Socio-demographic characteristics.

\begin{tabular}{cccc}
\hline & & N & $\%$ \\
\hline Age & $<25$ & 33 & 6.8 \\
& $26-35$ & 103 & 21 \\
Gender & $36-45$ & 221 & 45 \\
& $>46$ & 128 & 26 \\
Nationality & Male & 117 & 24 \\
Teaching discrete & Female & 368 & 76 \\
& Saudi & 485 & 100 \\
& Ahsaa villages & 180 & 37 \\
School type & ALHfoof & 154 & 31 \\
& AlMubaraz & 132 & 27 \\
Teaching level & HagrElAhasaa & 19 & 3.9 \\
& Governmental & 453 & 93.5 \\
& Special & 32 & 6.5 \\
& Kinder garden & 29 & 5.9 \\
& Primary & 197 & 40.6 \\
& Elementary & 103 & 21 \\
& Secondary & 156 & 32 \\
& Science & 242 & 50 \\
& Literature & 243 & 50 \\
& & &
\end{tabular}




\subsection{Awareness of Emergency Management of Epistaxis}

Fifty-four percentage of participants had received information about first aid to stop nose bleeding. Sixty-seven percent said that their students experienced epistaxis before. Interestingly, $15 \%$ said they would not try to stop the bleeding, and only $25 \%$ said they would press on the cartilaginous part of nose. Table 2 shows awareness regarding emergency management of epistaxis.

Table 2. Awareness regarding emergency management of epistaxis.

\begin{tabular}{|c|c|c|c|}
\hline & & $\mathbf{N}$ & $\%$ \\
\hline \multirow{2}{*}{$\begin{array}{l}\text { Have you ever received information about first aid } \\
\text { to stop nose bleeding or hemorrhage? }\end{array}$} & Yes & 264 & 54.4 \\
\hline & No & 221 & 45.6 \\
\hline \multirow[t]{2}{*}{ Have any of the students had epistaxis before? } & Yes & 326 & 67 \\
\hline & No & 159 & 32.7 \\
\hline \multirow{3}{*}{$\begin{array}{l}\text { If you experience bleeding, will you try to stop the } \\
\text { bleeding by pressing the nose? }\end{array}$} & Yes & 329 & 68 \\
\hline & No & 77 & 15.8 \\
\hline & Do not know & 79 & 16 \\
\hline \multirow[t]{3}{*}{ If yes, where exactly is the pressure? } & On the nose bone & 214 & 48 \\
\hline & Cartilage of the nose & 111 & 25 \\
\hline & Do not know & 119 & 26 \\
\hline \multirow[t]{5}{*}{ How long will you press the nose? } & $<2 \min$ & 114 & 23.5 \\
\hline & $2-5 \mathrm{~min}$ & 186 & 38 \\
\hline & $6-10 \mathrm{~min}$ & 34 & 7 \\
\hline & $11-20 \mathrm{~min}$ & 4 & 0.8 \\
\hline & Do not know & 147 & 30 \\
\hline \multirow{2}{*}{$\begin{array}{l}\text { Will you try to fill the nose with a } \\
\text { tissue or gauze? }\end{array}$} & Yes & 177 & 36.5 \\
\hline & No & 308 & 63.5 \\
\hline \multirow{2}{*}{$\begin{array}{l}\text { Will you try to stop bleeding by changing the head } \\
\text { position? }\end{array}$} & Yes & 334 & 68.8 \\
\hline & No & 152 & 31.2 \\
\hline \multirow[t]{2}{*}{ How do you change the head position? } & Tilt it forward & 204 & 57 \\
\hline & Tilt it backward & 152 & 43 \\
\hline \multirow[t]{2}{*}{ Will you try to put ice on your head or nose? } & Yes & 257 & 53 \\
\hline & No & 228 & 47 \\
\hline \multirow[t]{2}{*}{ Will you use other methods? } & Yes & 76 & 15.6 \\
\hline & No & 409 & 84.4 \\
\hline \multirow{5}{*}{$\begin{array}{l}\text { When do you think you should go to } \\
\text { an emergency? }\end{array}$} & Bleeding lasts $>10 \mathrm{~min}$ & 225 & 46 \\
\hline & Bleeding lasts $>30 \mathrm{~min}$ & 139 & 28.5 \\
\hline & Bleeding lasts $>60 \mathrm{~min}$ & 54 & 11 \\
\hline & Do not know & 34 & 7 \\
\hline & Do not think I will call for emergency & 33 & 6.8 \\
\hline
\end{tabular}




\subsection{The Relation between the Specialty and the Knowledge Level}

Our analysis showed no significant association between any of the baseline characteristics and level of knowledge except teachers' specialty. Literature teachers were more likely to agree on filling the nose with tissue or gauze to stop the nose bleeding $(\mathrm{p}=0.01)$. There was no association with other awareness questions. Table 3 shows the relation between specialty and knowledge level.

Table 3. Relation between the specialty and the knowledge.

\begin{tabular}{|c|c|c|c|c|}
\hline & & \multicolumn{2}{|c|}{ Specialty } & \multirow{2}{*}{ p-value } \\
\hline & & Science & literature & \\
\hline \multirow{2}{*}{$\begin{array}{l}\text { Have you ever received information about first } \\
\text { aid to stop nose bleeding or hemorrhage? }\end{array}$} & Yes & 166 & 98 & \multirow[b]{2}{*}{0.3} \\
\hline & No & 76 & 144 & \\
\hline \multirow[t]{2}{*}{ Have any of the students had epistaxis before? } & Yes & 130 & 195 & \multirow[b]{2}{*}{0.08} \\
\hline & No & 112 & 47 & \\
\hline \multirow{3}{*}{$\begin{array}{l}\text { If you experience bleeding, will you try to stop } \\
\text { the bleeding by pressing the nose? }\end{array}$} & Yes & 140 & 189 & \multirow{3}{*}{0.4} \\
\hline & No & 30 & 47 & \\
\hline & Do not know & 72 & 7 & \\
\hline \multirow[t]{3}{*}{ If yes, where exactly is the pressure? } & On the nose bone & 83 & 131 & \multirow{3}{*}{0.4} \\
\hline & $\begin{array}{l}\text { On the nose } \\
\text { cartilage }\end{array}$ & 51 & 60 & \\
\hline & Do not know & 67 & 52 & \\
\hline \multirow[t]{5}{*}{ How long will you press the nose? } & $<2 \min$ & 73 & 41 & \multirow{5}{*}{0.1} \\
\hline & $2-5 \min$ & 77 & 109 & \\
\hline & $6-10 \mathrm{~min}$ & 4 & 30 & \\
\hline & $11-20 \mathrm{~min}$ & 1 & 3 & \\
\hline & Do not know & 87 & 60 & \\
\hline \multirow{2}{*}{$\begin{array}{l}\text { Will you try to fill the nose with a tissue or } \\
\text { gauze? }\end{array}$} & Yes & 71 & 106 & \multirow[b]{2}{*}{$0.01^{*}$} \\
\hline & No & 171 & 137 & \\
\hline \multirow{2}{*}{$\begin{array}{l}\text { Will you try to stop bleeding by changing the } \\
\text { head position? }\end{array}$} & Yes & 91 & 113 & \multirow[b]{2}{*}{0.2} \\
\hline & No & 151 & 130 & \\
\hline \multirow[t]{2}{*}{ How do you change the head position? } & Tilt it forward & 98 & 106 & \multirow{2}{*}{0.1} \\
\hline & Tilt it backward & 107 & 45 & \\
\hline \multirow[t]{2}{*}{ Will you try to put ice on your head or nose? } & Yes & 149 & 108 & \multirow[b]{2}{*}{0.1} \\
\hline & No & 94 & 134 & \\
\hline \multirow[t]{2}{*}{ Will you use other methods? } & Yes & 30 & 46 & \multirow{2}{*}{0.8} \\
\hline & No & 212 & 197 & \\
\hline \multirow{5}{*}{$\begin{array}{l}\text { When do you think you should go to an } \\
\text { emergency? }\end{array}$} & Bleeding lasts $>10 \mathrm{~min}$ & 101 & 124 & \multirow{5}{*}{0.6} \\
\hline & Bleeding lasts $>30 \mathrm{~min}$ & 77 & 62 & \\
\hline & Bleeding lasts $>60 \mathrm{~min}$ & 21 & 33 & \\
\hline & Do not know & 15 & 19 & \\
\hline & $\begin{array}{c}\text { Do not think I will call for } \\
\text { emergency }\end{array}$ & 28 & 5 & \\
\hline
\end{tabular}

*Significant. 


\section{Discussions}

Epistaxis is one of the commonest presenting symptoms to ENT physicians as well as to family and emergency physicians [10]. Sixty-seven percent said that their students experienced epistaxis before. Similar studies showed that teachers agreed that epistaxis is among the most common injuries due to sports or playing and is common in primary school children [11]. Even though, $45 \%$ never received information or training about epistaxis management and 15\% said they would not try to stop the bleeding. Teachers should be the first respondents in school as they attend such accidents and always in a position to do first aid [5]. First aid training was found to be very helpful as a study found that $72 \%-80 \%$ primary school teachers improved their knowledge and continued practice regarding first aid management for emergency conditions in school campus [12].

Our results showed low level of awareness about common first aid management of epistaxis. It was unexpected that only $25 \%$ knew that pressing the lower cartilaginous part of nose can stop the bleeding and $26 \%$ said they do not know. The lower part of the nose is where the Little's area is. It is the most likely site of the bleeding point [13]. Fifty-seven percent knew that head should be tilted forward. Tilting head forward, facilitates clot formation and avoids a steady trickle into the post-nasal space [14].

Almost half of teachers agreed to put ice on head or nose and 36\% would insert a tissue or gauze in the nose. Over the years, a number of methods for stopping a nose bleed have been advocated but the documented most satisfactory method is pressing the lower part of nose with tilting the head forward [15].

Forty-six percent of teachers said that they would go to the emergency department if bleeding lasts more than $10 \mathrm{~min}$. Only $10 \%$ of epistaxis cases need a medical specialist intervention [5]. Most epistaxis will stop with correct first aid management, which is less time and money consuming and remove the need for a visit to the Emergency Department and subsequent ENT referral.

\section{Conclusion}

The ignorance of the teachers' awareness, which certainly reflects the public ignorance on this subject, should be taken seriously. It is important to notice that teachers should better be trained to apply epistaxis management. In this study, we tried to investigate how teachers would attempt to stop a nose bleeding and compare this with the standard method advocated above. Future first aid training programs should be considered in schools and among community.

\section{References}

[1] Douglas, R. and Wormald, P. (2007) Update on Epistaxis. Current Opinion in Otolaryngology \& Head and Neck Surgery, 15, 180-183. https://doi.org/10.1097/MOO.0b013e32814b06ed

[2] Lang, F. (2009) Encyclopedia of Molecular Mechanisms of Disease. Springer, Berlin. https://doi.org/10.1007/978-3-540-29676-8 
[3] Olympia, R. (2005) The Preparedness of Schools to Respond to Emergencies in Children: A National Survey of School Nurses. Pediatrics, 116, e738-e745. https://doi.org/10.1542/peds.2005-1474

[4] Sapien, R. and Allen, A. (2001) Emergency Preparation in Schools: A Snapshot of a Rural State. Pediatric Emergency Care, 17, 329-333. https://doi.org/10.1097/00006565-200110000-00003

[5] Sharma, R., Kumar, A. and Masih, S. (2014) Knowledge and Practice of Primary School Teachers about First Aid Management of Selected Minor Injuries among Children. International Journal of Medicine and Public Health, 4, 458. https://doi.org/10.4103/2230-8598.144114

[6] Joseph, N., Narayanan, T., bin Zakaria, S., Venugopal Nair, A., Belayutham, L., Mihiraa Subramanian, A., et al. (2015) Awareness, Attitudes and Practices of First Aid among School Teachers in Mangalore, South India. Journal of Primary Health Care, 7, 274. https://doi.org/10.1071/HC15274

[7] Sonmez, Y., Uskun, E. and Pehlivan, A. (2014) Knowledge Levels of Pre-School Teachers Related with Basic First-Aid Practices, Isparta Sample*. Turkish Archives of Pediatrics, 49, 238-246. https://doi.org/10.5152/tpa.2014.1581

[8] Vikas, B., Mangat, S. and Amrit Pal, K. (2009) An Intervention Study to Strengthen First Aid Care in Schools of Chandigarh, India. The Internet Journal of Family Practice, 8.

[9] Raosoft.com (2015) Sample Size Calculator by Raosoft, Inc. http://www.raosoft.com/samplesize.html

[10] Rockey, J.G. and Anand, R. (2002) A Critical Audit of the Surgical Management of Intractable Epistaxis Using Sphenopalatine Artery Ligation/Diathermy. Rhinology, 40, 147-149.

[11] Wilson, C. (1930) First Aid Cabinet of a School Nurse, Her Standing Orders for First Aid, and Her School Nursing Procedure. American Journal of Public Health and the Nations Health, 20, 147-154. https://doi.org/10.2105/AJPH.20.2.147

[12] Ali, S., Abu-Eleoud, A., Heybah, S. and Mohamed, A. (2010) Implementation of an Educational Training Program in First Aid for Newly Graduated Nursery School Teachers at Zagazig City. Zagazig Journal of Occupational Health and Safety, 3, 20-29.

[13] Bailey, H. and Love, R. (1948) A Short Practice of Surgery. 21st Edition, Lewis, London.

[14] Pearson, B. (1975) Epistaxis. Postgraduate Medicine, 57, 116-119. https://doi.org/10.1080/00325481.1975.11714052

[15] Strachan, D. and England, J. (1998) First-Aid Treatment of Epistaxis-Confirmation of Widespread Ignorance. Postgraduate Medical Journal, 74, 113-114. https://doi.org/10.1136/pgmj.74.868.113 


\section{Appendix}

A Questionnaire that Measures School Teachers Awareness Regarding First Aid Management of Nasal Bleeding or Epistaxis-AlAhsa-Kingdom of Saudi Arabia

- Age:
- Under 25.
- $26-35$
○ $\quad 36-45$
- $\quad$ Above 46

- Gender:
○ Male.
○ Female.

- Nationality:

○ Saudi.

○ Non-Saudi.

- Teaching discrete:
- Ahsaa villages.
- ALHfoof.
- AlMubaraz.
- Hagr ElAhasaa.

- School type:

- Governmental.

- Special.

- Teaching level:

- Kindergarten.

- Primary school.

- Intermediate school.

- Secondary school.

- Teacher specialty:
- Scientific.

○ Literature.

- Have you ever received information about first aid to stop nose bleeding or epistaxis?
$\circ$ Yes.
- No. 
- Had any student or school staff ever suffered a nose bleeding or epistaxis?

○ Yes.

○ No.

- If you experience bleeding, will you try to stop bleeding by applying pressure on the nose?

- Yes.

○ No.

- If yes, where exactly is the pressure?

- Upper part of the nose.

$\circ \quad$ Lower part of the nose.

- For how long will the press the nose?

- Less than 2 minutes.

- 2 - 5 minutes.

○ 6 - 10 minutes.

- $\quad 11-20$ minutes.

- More than 20 minutes.

- Will you try to fill the nose with a tissue or gauze?

$\circ \quad$ Yes.

○ No.

- Will you try to stop bleeding by changing the head position?

- Yes.

○ No.

- How do you change the head position?

- Till it forward.

- Till it backward.

- Will you try to put ice on the head or the nose?

$\circ \quad$ Yes.

○ No.

- Will you use other methods?

○ Yes, mention it?

$\circ \quad$ No

- When do you think you should go to the emergency?

$\circ \quad$ I do not think it needs an emergency. 
If the bleeding lasts more than 10 minutes.

- If the bleeding lasts more than 30 minutes.

○ If the bleeding lasts more than 60 minutes.

- I don't know. 


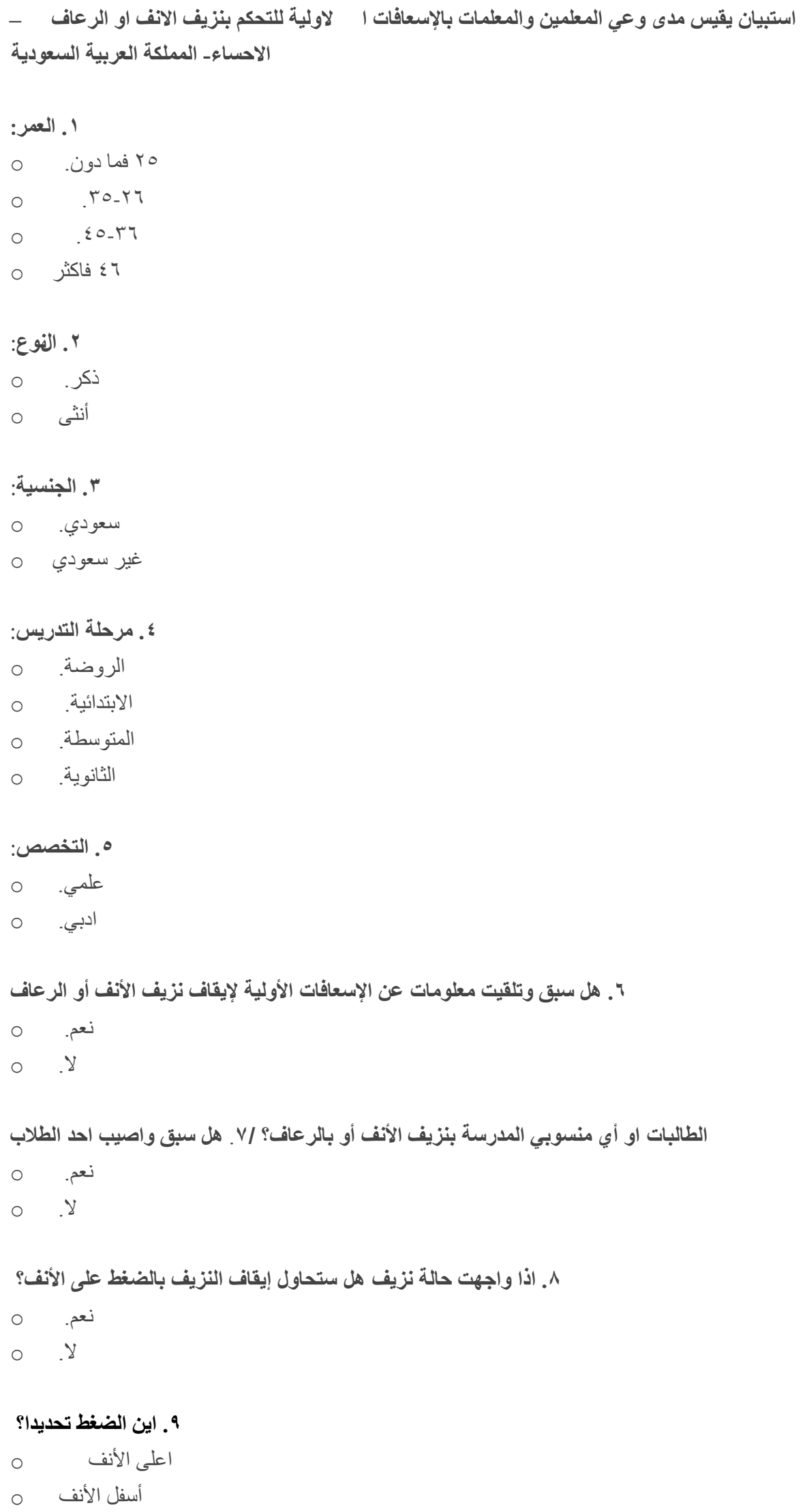


. 1 . كم ستستمر من الزمن في ضغط الأنف؟

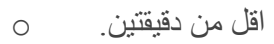

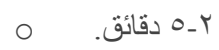

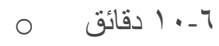

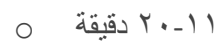

اكثر من ·r د دقيقة

1 ـ هل ستحاول سد الأنف بمنديل أو شاش؟

ن نعم.

0 . ע

r ا ـ هل ستحاول إيقاف النزيف بتغيير وضعية الراس؟

ن نعم.

0 . ע

r 1 ـ كيف ستقوم بتغير وضعية الراس ؟

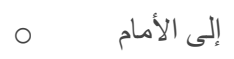

إلى الخلف

ء 1 هل ستحاول وضع الثلج على الراس أو الأنف؟

ن ن الעم.

○. لا ن

1 . هل ستستخدم طرق أخرى؟

ن ن نعم، ماهي؟

○ V

1 ا ـ متى تعتق أنه يتوجب عليك التوجه إلى الطوارئ؟

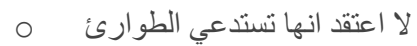

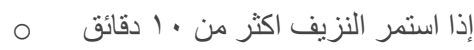

اذا استمر النزيف اكثر من · بـ دقيقة

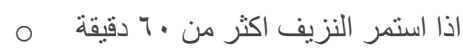

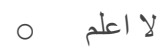

